Raab, E. and Lipset, S.M., Prejudice and Society, in Rose, A.M. and Rose, C.B. (eds.), Minority Problems, New York 1965, 361-371 (first published in 1959).

Rose, P.J., They and We. Racial and Ethnic Relations in the United States, New York 1974.

Salowsky, $H_{2}$ Gesamtwirtschafuliche Aspekte der Ausländerbeschäftigung. Beiträge des Deutschen Industrieinstituts, IX, Köln 1971

Schrader, A., Nikles, B.W. and Griese, H.M., Die zweite Generation. Sozialisation und Akkulturation ausländischer Kinder in der Bendesrepublik, Kronberg 1976

Sherif, M., and Sherif, C.W., Social Psychology, New York-Evanston-LondonTokyo 1969.

Thomas, W.J. and Znaniecki, F., The Polish Peasant in Europe and America, 2 Vols., Boston and New York 1958.

Wagner, A., Wirtschaftswachstum ohne Gastarbeiter? Uberlegungen zu einer konflicktfreien Verbindung bevölkerungs- und wirtschaftspoliti scher Ziele, in Kaufmann, F,X. (ed.), Bevólkerungsbewegung zwischen Quantität und Qualität, Stuttgart 1975, 148-161.

Warner, W.L. and Srole, L., The Social System of American Ethnic Groups, Yankee City Series, Vol. III, New Haven 1945.

Wieduwilt, M. und Jürgens, H.W., Einstellungen der deutschen Bevölkerung und der ausländischen Arbeitnehmer, in Konrad-Adenauer-Stiftung Integration ausländischer Arbeitnehmer. Eingliederung, Einstellungen, Weiterbildung, Bonn 1976, 52-169.

Zubaida, S. (ed.), Race and Racialism, London-New York-Sidney-TorontoWellington $1970(a)$.

$-1970(B)$, Intraduction to $1970(\mathrm{a})$.

\section{THE AMERICAN AGRICULTURE MOVEMENT: MANIFEST AND LATENT PARTICIPANT ATTRACTIONS IN A SOCIAL MOVEMENT*}

Gary S. Foster

Kansas State University

Mid-American Review of Sociology, 1980, Vol. V, No. 2:31-46

\section{INTRODUCTION}

This paper will focus on the recently organized American Agriculture Movement (AAM) in the context of a social movement. Upon approaching the AAM as a topic of research, one is immediately confronted by the paucity of literature in the professional sociology and agricultural economics journals. This is not to suggest that the AAM has been rejected as an area worthy of research, but is probably due to research lag. Indeed, the 1978 Wisconsin Farmer Survey conducted by the University of Wisconsin's Department of Rural Sociology, among other data collection, solicits information addressing support of the AAM (Wilkening, 1978:7). Of necessity then, most of the data addressing the AAM have been drawn from news periodicals, newspapers, and various agricultural and farm journals.

Even given the probable accessibility of other and more diverse data sources (e.g., surveys and questionnaires involving AAM members, interviews with AAM leaders and members, participant observation in district offices, and so on), there are certain advantages inherent in the sources of data utilized in this paper. First, such data seem sufficient for an initial investigation of the AAM. Second, in the absence of journal articles and other literature, the more "popular" data sources must be dealt with in order to have more specific direction for further investigation,

* I am grateful to Professor Wayne Rohrer of Kansas State University and Professor Edward McLean of Clemson University for their comments and criticism of this research. A version of this paper was presented at the 1980 Annual Meeting of Rural Sociology Section, Southern Association of Agricultural Scientists, February 3-6, Hot Springs, Arkansas. 
i.e., to establish a point of departure. Third, given the specific focus of this paper, a disproportionate amount of time would be required for prinary data collection. Fourth, the data under consideration are the data largely available to the public at large, and as such, could later facilitate research into public perception of the AAM. That is, it is assumed that the general public's conception and understanding of the American Agricultural Moveception and from the same (sort of) data sources employed here. Further, such data sources, by reporting the espoused goals of the AAM, present the public with a seeming paradox: why does an apparently economically well-off group form what purports to be an economic protest group? This paper will focus upon the manifest and latent attractions for participation in the AAM, largely expressed through the ideology of the movement. The paradox diminishes with consideration of latent attractions.

\section{THE AAM AS A SOCIAL MOVEMENT}

Social movements have been variously defined, but each share two common elements-the group and its actions to effect (or resist) change (e.g., see King, 1956:27; Toch, 1965:5; Turner and Killian, 1957:308; Blumer, 1969:8; Cameron, 1966:7; Morrison and Steeves, 1967:414-5; Zald and Ash, 1966:329; Zald and McCarthy, 1972:670). Taylor (1953:1; see also Taylor, 1949: $511,518)$, in the specific context of farm and agricultural movements, states that "a movement is a type of collective behavior by means of which some large segment of society attempts to accomplish adjustments of conditions in its economy or culture which it thinks are in maladjustment." With respect to the group, the $\mathrm{A} \overline{\mathrm{AM}}$, a national organization initiated in mid-September of 1977 , spread rapidly out of Springfield, Colorado (Cook, 1977:53, 60; Powers, 1978:A1, A6). Presently, there are AAM offices in at least forty-one states ("Kansas Farmers Plan Tractor Rally," 1978:5), with prominent support coming from the wheat-belt states ("Plowshares into Swords," 1977:28; "Behind the Unrest of America's Farms," 1977:70). More significantly, AAM claims support from 1.1 million (forty percent) of the nation's 2.75 million farms ("Behind the Unrest of America's Farms," 1977:70).
The problem or "maladjustment" that the AAM participants have perceived is economic deprivation ("Furious Farmers," 1977:17; "Why Farmers Are Up in Arms," 1978:25-7), a problem that has accompanied commercial agriculture throughout history and has apparently been the impetus, at least in part, for past agricultural discontent and organizations (Taylor, 1949:510-21, Morrison and Steeves, 1967:414-34; Morrison and Warner, 1971: 5-19; Bemis, 1893:193-213; Drew, $1891: 282-310$ ).

The AAM, as well as its ideology, may be viewed as a direct response to a created agricultural depression. Most U.S. agricultural authorities, including many farmers, contend that the present low price level is the result of a bust end of a production cycle that developed in 1973-74. In 1972-73, a three percent decrease in the world's grain production resulted in a 250 percent demand and price increase in world grains (Goldberg, 1975:81-3). In response, USDA's Secretary, Earl Butz, urged farmers to "plant fencerow to fencerow" to meet the world's food demand. Farmers were encouraged to expand their operations and equipment (via loans, using their land as collateral) by doubled wheat prices and increased soybean and corn prices. As world demand declined with improved oversees yields, the farmers were faced with debts and falling prices. To meet debt payments, they continued to produce, often "fencerow to fencerow," driving prices down even further. Increased land value also brought about higher taxation of expanded operations (Barish, 1978:1, 9; "Another Losing Year," 1977:30). Thus, AAM's main objective is to bring farmers together to plan courses of action in order to eliminate or favorably alter their position relative to their perceived economic deprivation.

Taylor $(1949: 510-21 ; 1953)$ has analyzed numerous farm movements and their histories, and his observations are particularly relevant to the AAM. Historically, the high tides of farmer discontent and unrest in the United States have occurred almost entirely during periods of agricultural depressions, when farmers found themselves at a relative disadvantage in relation to prices, markets, and credits. Indeed, the large farmers' organizations have come into existence quite consistently during periods of depression. Further, only the high tides of farmer discontent have been characterized by public displays of social unrest. "The 
farmers' movement has seldom if ever been recognized in terms other than those of open rebellion and demands for relief legislation" (Taylor, 1949:511). Certainly, the AAM may be readily identified as a high tide in the farmers' movement, and to this extent, Taylor (1949:521) would identify it as the latest link in the chain of one farmers' movement running through U.S. agricultural history.

With respect to a sociological identification of the AAM as a social movement, Smelser's $(1962: 270,313)$ norm-oriented movement (as opposed to value-oriented movement) seems particularly relevant. This is quite similar to Blumer's (1969:20-2) reform/revolution movement dichotomy. "A norm-oriented movement is an attempt to restore, protect, modify, or create norms in the name of a generalized belief.... Any kind of norm-economic, educational, political, religious-may become the subject to such movements" (Smelser, 1962:270). Tactically, the AAM appears to be shifting from a norm-oriented to a value-oriented movement since it has perceived such legitimate channels as lobbying and offering and soliciting political support as being ineffective, and thus has engaged in other tactics (Smelser, 1962:284).

However, the peace, poverty, and civil rights movements of the sixties did much to lend greater legitimacy to marches and demonstrations, just as the labor movement did much to legitimize strikes (Etzioni, 1971). Further, federal antitrust laws do not prohibit farmers from striking (G. Smith, 1978:22). Thus, even AAM's threat of withholding produce and buying boycotts (Schneider, 1978:18; Vankirk, 1978:22a) may be conceived of as working completely within the system to effect the desired change. One tactic suggested but not yet pursued by AAM members was the proposal to withhold county, state, and federal taxes, the defense being that the courts are incapable of handling several hundred thousand tax cases at one time (Vankirk, 1978; 22a). The lack of such action implies that the AAM is still willing to work within the system.

Also of particular relevance in characterizing the AAM is the inclusive/exclusive organization classification proposed by Zald and Ash (1966:330-1). The AAM would seem to constitute an inclusive movement, requiring of its members only a minimum level of initial commitment-a pledge of general support without specific duties and dues, and no indoctrination or "novitiate" period. Further, the AAM has no memberships or presidents (Curry, 1978:9; "American Agriculture Movement," 1977). Apparently, for the AAM, a pledge of general support might take a form, at least to some extent, of financial donations. The finan cial support of each district office within each AAM state comes largely from contributions by participating farmers (Curry, 1978: 9; Powers, 1978:A1, A6).

Further, an inclusive movement "... requires little activity from its members-they can belong to other organizations and groups unselfconsciously..." (Zald and Ash, 1966:331). Thus, while established farm organizations are not endorsing the AAM (Nicholson et al., 1977:57; "Behind the Unrest on America's Farms," 1977:69-70), there is no reason to assume that many participating farmers are not members of the American Farm Bureau Federation, National Farmers' Organization, or other farm organizations. Possibly because of its inclusive nature, the AAM has been described and perceived as a "loose national organization" (Barish, 1978:1).

Killian's (1964:448-52) power-oriented/participation-oriented movement classification is particularly relevant in addressing the manifest and latent attractions for participation. The AAM, as espoused by its ideology, is primarily a power-oriented movement, with coordinated group actions thought to be the necessary means for obtaining the desired change. However, a closer examination of AAM's ideology suggests that it, at least latently, approaches a participation-oriented movement in which group actions are viewed as the sources of benefits or gratifications for the individual participants.

\section{MANIFEST ATTRACTIONS FOR AAM PARTICIPATION}

Because manifest attractions are intended, it would be expected that such attractions are clearly stated in the movement's ideology. Blumer (1969:19) recognizes the significance of an ideology to a social movement, providing a movement with 
its philosophy and psychology, and doubting any kind of temporal existence for the movement without an ideology.

A social movement comes to be identified and recognized by its ideology in that the ideology is the framework for maintaining the movement, directing its behavior and actions, and recruiting participants. Thus, the ideology provides the movement with objectives, justification, weapons of attack and defense, and inspiration and hope. Further, the popular character of the ideology, as opposed to its abstract and ambiguous character, assumes emotional symbols, shibboleths, stereotypes, and folk arguments, and without the popular appeal, the ideology would be of little value to the movement (Blumer, 1969:19-20); see also, Gerlach and Hine, 1970:159-82; Smelser, 1962:8-22, 47-81). However, the ideology is not static. The ideology, particularly its stated goals and objectives, is subject to change. It may be modified and redefined to preserve the movement and maintain members who no longer perceive the original goals as realistic (e.g., see Cameron, 1966:27, 32; Zald and Ash, 1966:334-5).

With respect to objectives, the AAM has specified a five point goal (i.e., the manifest attractions) which involves the following: 1) one hundred percent parity for all domestically consumed and exported agricultural products; 2) one hunderd percent parity for all products held in reserve; 3) creation of a coalition of agricultural producers to participate in governmental formulation of farm bills; 4) cease all food imports which are also domestically produced until one hundred percent parity is obtained; and 5) all announcements pertaining to any agricultural production cycle shall be made well in advance, allowing producers adequate time to make needed adjustments in operations. The five points are often condensed into the shibboleth, "parity." Another demand posed by the AAM is the election, rather than appointment, of Agricultural Stabilization and Conservation Service county administrators ("Farm Strikers Talk to Agriculture Secretary," 1978:A8).

Thus, participation in the AAM would be particularly attractive to those who have perceived a relative economic deprivation, and indeed, the expressed purpose of AAM is to deal effectively with this economic deprivation. Within the context of relative deprivation, Morrison (1971:677) contends that the manifest goals of any power-oriented movement must become "...(1) legitimate expectations that are (2) perceived as blocked." Expectations become legitimate through learning that certain investments (e.g., "planting fencerow to fencerow") are generally rewarded by certain outcomes, and such learning is most poignant when actual behavioral reinforcement is present (e.g., high agricultural prices in 1972-73). Such an expectation was given further legitimacy by the federal government's encouragement of agricultural expansion. Accompanying the agricultural depression in 1974 was a blockage of aspirations through a decline in opportunities. That is, the farmers began to decline on the economic continuum and experienced deprivation relative to their former positions, what Morrison and Steeves (1967:433) term "decremental" relative deprivation. The belief in blockage comes to be held as a belief in structural blockage (e.g., the federal government and their actions), and attempts at reduction pursue a belief in a structural solution (e.g., the AAM). The beliefs in structural blockage and structural solutions then emerge and develop the psychology and ideology of the social movement. That is, there is an interactive feedback between blockage and solution to produce goals and objectives, here embracing the diminution of economic deprivation as the manifest attraction (Morrison, 1971:678, 684).

Yet, a tactical error by the AAM has potentially led some non-participants to express the general paradox, "this is the richest-looking group of broke people I've ever seen" (Nicholson et al., 1977:57). In using 35,000 dollar tractors as protesting billboards and planning six million dollar tractorcades (Powers, 1978:A1, A6; see also, L. Smith, 1978:94), the AAM has not emphasized that the economy now demands such equipment for successful farming (if, indeed, it does), potentially making it difficult for the general public to acknowledge legitimacy for the perceived economic deprivation. There is then presented to the public a paradox between the apparent economic status of AAM participants and their perceived economic deprivation. However, Morrison and Steeves (1967:422-4; see also, Morrison, 1971:675, 
681) note that the ones experiencing the greatest economic deprivation, the marginal farmers, are normally not participants in social movements. Thus, it is suspected that the participants are those who were "successful" prior to the 1973-74 expansion, and, in expanding, now perceive economic deprivation and loss. Supporting this contention to some extent are the status positions of the founders of $A A M$, including a veterinarian, a physicist, and the vice-chairman of the Colorado Highway Commission (Cook, 1977.53). Indeed, farm debt has doubled to 101 billion dollars since 1970 ("Plowshares into Swords," 1977:28), and much of this debt was undoubtedly assumed by those who expanded their operations during the prosperity of 1972-73. Thus, economic deprivation must be considered the manifest impetus for, and attraction to, the AAM.

However, much of the social movement literature addresses only the primary or manifest factor, reducing the movement to some mono-causal response. Barish (1978:1) seems to sense the fallacy of a mono-causal factor, saying, "on the surface the protest is in response to low farm prices, but the plight of farmers is a complex issue which has vexed policy makers and politicians for almost a century." Thus, it would seem heuristically advantageous to propose potential, latent attractions.

\section{LATENT ATTRACTIONS FOR AAM PARTICIPATION}

The ideology of a movement, either explicitly or implicitly, should indicate attractions other than the manifest one(s) for participants and potential participants. That is, even non-goal activities are part of the psychology of the movement and therefore must be considered part of the ideology, explaining even further the extent of the ideology's popular appeal.

In that Morrison (1971:675) and Glock and Stark (1965: 249) note the central variable of shared deprivation in the rise focial movements, it would be feasible to conceive of difof social movements, it would be feasible to canceive levels of faction to the movement. Zald and Ash (1966:329) recognize this, identifying three levels of incentives. Olson (1965:51, $60-4,133-4,153-9)$, in noting the increased costs incurred by individuals in a group endeavor, contends that the group must employ separate and selective incentives which are benefits other than the main objectives the group is seeking.

Beyond economic deprivation, Glock and Stark (1965:246. 57; also, Glock, 1964:26-36) identify four other types of deprivation. The desires to overcome such deprivations might then be grounded in the popular appeal of AAM participation. Glock and Stark's (1965:247) social deprivation, “... based on society's propensity to value some attributes of individuals and groups more highly than others and to distribute such societal rewards as prestige, power, status, and opportunities for social participation accordingly," might constitute a latent level of attraction. This is analogous to Zald and Ash's (1966:329) secondary role of solidary incentives (prestige, respect, friendship). Conceivably, this might also be considered "decremental" relative deprivation (Morrison and Steeves, 1967:433), the farmers declining or remaining stationary on the social continuum while others were upwardly mobile.

Further interpretation might suggest that while the farmer has not remained stationary, the perception of the occupation has. Historically then, the farmer has not been accorded the prestige that the occupation received when more people were engaged in farming. Taylor (1949:511), in recognizing the significance of social status, states that the farm movement

... has never been thought of as a significant historic movement growing out of deep and persistent maladjustments between the... social status of rural people on the one hand; and... social status of people in other fields of endeavor.

Factors such as the consolidation of rural schools, the loss of rural community identity, the yearly conversion of five million acres of farm land to urban or industrial use ("Plowshares into Swords," 1978:28), and the perception of economic deprivation probably have had some impact on the farmer's self-perception and on others' perceptions of him. Indeed, Taylor (1949:522-33) briefly discusses the impact of changing methods of security, declining primary associations, the loss of folk arts and skills, 


\section{Mid-American Review of Sociology}

and other factors potentially relevant to status perception. Thus, participation in the AAM potentially facilitates the farmer's sense of support, status, prestige, and even recreation (see Blumer, 1969:16).

Certainly, the political influence of the once-powerful farming public has declined with their numbers, urban congressmen outnumbering rural congressmen 400 to thirty-five in the U.S. House of Representatives. In terms of voting power, the farming public comprises less than four percent of the population, declining from twenty-five percent in 1930 ("Why Farmers Are Up in Arms," 1978:26). Demanding the elections of ASCS county administrators and endorsing political candidates is then viewed as an attempt by AAM to recoup rural, political influence (for such political endorsements, see AAM Kansas Newsletter, 1978). Facilitating family involvement is the women's auxiliary, American Agri-Women, which enables more complete participation by wives ("Plowshares in Swords," 1978:28), AAM rallys, picnics, celebrations at the local level. Such events serve as stages for interacting and elevating esprit de corps. Responses to social deprivation may then compensate for a perceived lack of status by providng alternative status systems, e.g., clubs and lodges (Glock and Stark, 1965:251).

Ethical deprivation, i.e., perceiving discrepancies between ideals or espoused values and realities, may also constitute a secondary or latent attraction for participation in the AAM. "Indeed, the ... right wing activity in American politics seems to stem to a great extent from the perceptions of ... rural Americans that their traditional values are no longer predominant in ... society" (Glock and Stark, 1965:253). Certainly, such ethical deprivation could contribute to the perception of status depriva tion.

Occupationally, farming is accorded much value, at least superficially. The American farmer is pedestaled as the leading agricultural production power of the world, and Senator Talmage notes: "We were founded as a nation of farmers. It remains true that the welfare of the whole community depends on the farmer" ("Why Farmers Are Up in Arms," 1978:27). Yet, the 160 acre farmer is told that he can no longer make it ("Why Farmers Are Up in Arms," 1978:25). Thus, a perception of economic and
The American Agriculture Movement

social deprivations would almost necessitate a perception of discrepancy between values and reality; economic and social securities may then function as manifestations and indicators of the reality of particular values.

Tactics employed by the AAM may be instrumental in overcoming various types of perceived deprivation. The media are utilized through television (Powers, 1978:A1) and paid radio spots to "educate" farmers and consumers (AAM Kansas Newsletter, 1978). Zald and McCarthy (1972:670) note the increased status and legitimacy extended to movements by television utilization. Hunters and fishermen have found land access is often barred with "AAM: No Hunting, Fishing, or Trespassing" signs, transforming AAM's status to a private sports club.

One of the more publicized tactics has been the tractorcades. Indeed, it seems that this particular activity, at least at the county and state levels, potentially becomes the nucleus for family involvement (J. Smith, 1978:14-6; Nicholson et al., 1977:57). Much of the tractorcade involvement constitutes ceremonial behavior with the ritualistic paraphernalia, such as the slogans attached to tractors, songs, and cheers, fostering feelings of common identity. Blumer (1969:16) notes that

... the value is one that comes from large assemblages, in the form of the sense of vast support that is experienced by the participant. The psychology that is involved here is the psychology of being on parade. The individual participant experiences the feeling of considerable personal expansion and therefore has the sense of being somebody distinctly important.

The tactics employed by the AAM have drawn nationwide recognition for the American farmer. While this may not bring about a decline in the perceived economic deprivation, the "limelight" may potentially disperse the darkness of other types of deprivation. Further, the relative failure of specific tactics, such as withholding and striking (i.e., not planting), would indicate that many members are willing to participate socially and philosophically, but not absolutely. A consideration of latent attractions would then suggest that the AAM is more than an economic 
protest group and that the paradox exists when only the manifest attraction is considered.

\section{CONCLUSIONS}

The future of this latest link in the chain of farmer's movements is uncertain. Indeed, AAM's perception of economic deprivation is given little credence by the federal government. President Carter contends the farmers are no longer on the verge of bankruptcy ("Farmers Not Impressed with Carter's Image," 1978:A1), and USDA claims farm prices are again rising "Behind the Unrest on America's Farms," 1977:70; "Furious Farmers," 1977:17). With the 1977 farm bill raising subsidies from 345 million dollars to seven billion dollars (L. Smith, 1978:94), and agricultural economists contending that one hundred percent parity would cost as much as forty billion dollars (Barish, 1978: 9), the government's apparent attitude is that it has done all it can.

To this extent, the government constitutes an out-group within the in-group/out-group relationship, thus providing solidarity and esprit de corps to AAM (Blumer, 1969:15-6). However, if AAM's goals are indeed unobtainable, then it would seem that to survive, AAM will have to change its goals, perhaps embracing more immediate and individual attractions. For example, since the initial draft of this paper, AAM has been discussing ninety percent of parity as an acceptable goal. Facilitating a perceived elevation of status (in the occupation of farming) was the government's gesture of unlimited fuel allocation for harvesting activities. However, as petroleum fuels become increasingly scarce, the interface between energy concerns and large-scale, "fencerow to fencerow" agriculture will become another rallying point for the next link in the chain of farmer's movements. Further, while AAM has been able to mobilize a wide variety of farmers, "farmers differ so much in nature of their enterprises and the problems they face that it is hazardous to treat them as an undifferentiated population..." (Morrison and Warner, 1971:15). Thus, AAM's position with respect to its following is precarious, and a shift toward more specific goals may be to the disinterest of many members, or even create an opposition group of farmers. Potentially then, this latest link is a weak one.

This paper is exploratory, speculative, and preliminary rather than definitive. However, it is suggestive of research focusing on propositions of latent attractions, and the data suggest such inquiry is a viable area for future empirical research. Specific areas potentially fruitful for hypotheses generation and testing include public perception of any paradox as well as participant perception of this paradox (perhaps within the framework of conflict or cognitive dissonance/consonnance). The empirical assessment of manifest and latent attractions would seem quite valuable, particularly their relationships to goal changes and shifts. Are manifest goals simply altered or are latent goals elevated to manifest statuses and what are the impacts of each type of change upon the future and direction of AAM? These are areas that must be given consideration in future research on any social movement.

\section{REFERENCES}

Anonymous

1978 AAM Kansas Newsletter, Vol. 1, No. 3 (July 21) Johnson, Kansas.

1977 "American Agriculture Movement," fact sheet prepared by AAM national headquarters, Box 57, Springfield, Colorado.

1977 "Another Losing Year." Time (October 24):30.

1977 "Behind the Unrest on America's Farms." U.S. News and World Report (December 26):69-70.

1978 "Farm Strikers Talk to Agriculture Secretary." The Sacramento Bee (January 7):A8.

1978 "Farmers Not Impressed with Carter's Image." The Manhattan Mercury, Manhattan, Kansas (October 23):A1.

1977 "Furious Farmers." Time (December 19):17.

1978 "Kansas Farmers Plan Tractor Rally." Kansas State Collegian, Kansas State University (November 14):5.

1977 "Plowshares into Swords." Time (October 24):28, 30.

1978 "Why Farmers Are Up in Arms." U.S. News and World Report Barish, Bob (April 17):25-7

1978 "Protesting Farmers Seek New Ag Policy." Family Farm Uanuary 30): $1,9$.

Bemis, Edward W.

1893 "The Discontent of the Farmer," Journal of Political Economy Vol. 1, No. 2 (March):193-213. 
Blumer, Herbert

1969 "Social Movements." in Barry McLaughlin (ed.), Studies in Social Movements: A Social Psychological Perspective, New York: The Free Press.

Cameron, William Bruce

1966 Modern Social Movements. New York: Random House.

Cook Gay

1977 "Ag Strike Movement Born in Colorado." The Denver Pos

Curry, Rich (December 4): 53,60

1978 "AAM Tractorcade to Rumble East in Parity Demand." Kans: Drew, F.M. State Collegian, Kansas State University (December 7):9.

1891 "The Present Farmers' Movement." Political Science Quarterly Vol. 6, No. 2 (June):282-310.

Etzioni, Amitai

1971 Demonstration Democracy. New York: Gordon and Breach Science Publishers.

Gerlach, Luther P. and Virginia H. Hine

1970 People, Power, Change: Movements of Social Transformation Indianapolis: Bobbs-Merrill Company.

Glock, Charles $\mathrm{Y}$.

1964 "The Role of Deprivation in the Origin and Evolution of Reli gious Groups." in Robert Lee and Martin E. Marty (eds.), Reli gion and Social Conflict. New York: Oxford University Press.

Glock, Charles Y. and Rodney Stark

1965 Religion and Society in Tension. Chicago: Rand McNally.

Goldberg, Ray A.

1975 "U.S. Agtibusiness Breaks Out of Isolation." Harvard Business Review Vol. 53, No. 3 (May/June):81-95.

Killian, Lewis $M$

1964 "Social Movements." in R.E.L. Faris (ed.), Handbook of Modern Sociology. Chicago: Rand McNally.

King, C. Wendell

1956 Social Movements in the United States. New York: Random House.

Morrison, Denton $\mathrm{E}$

1971 "Some Notes Toward Theory on Relative Deprivation, Social Movements, and Social Change." American Behavioral Scientist Vol. 14, No. 5 (May/June):675-90.

Morrison, Denton E. and Allan D. Steeves

1967 "Deprivation, Discontent, and Social Movement Participation: Evidence on a Contemporary Farmers' Movement, The NFO? Journal of Rural Sociology Vol. 32, No 4 (December):414-34.
Morrison, Denton E. and W. Keith Warner

1971 "Correlates of Farmers' Attitudes Toward Public and Private Aspects of Agricultural Organization." Journal of Rural Sociology Vol. 36, No. 1 (March):5-19.

Nicholson, Tom, John Walcott, Dewey Gram, and Frank Maier

1977 "The Tractor Rebellion." Newsweek (December 19):57.

Olson, Mancur, Jr.

1965 The Logic of Collective Action: Public Goods and the Theory of Groups. Cambridge, Mass.: Harvard University Press.

Powers, Uteva

1978 "AAM Strike Gaining Vigor." The Manhattan Mercury, Manhattan, Kansas (October 13):A1, A6.

Schneider, L.W., Jr.

1978 "Kansas Farmer Readers Say." Kansas Farmer (January 7):18.

Smelser, Neil J.

1962 Theory of Collective Behavior. New York: The Free Press.

Smith, George L.

1978 "The Strike Rolls On," Kansas Farmer (January 7):22.

Smith, Jim

1978 "The Armisteads of Kentucky Fight to Keep a Family Farm." Smith, Lee Senior Scholastic (April 20):14-6.

1978 "Farm Income Will Rise Again." Fortune (February 27):94-5, 97,100

Taylor, Carl C.

1949 "The Farmers' Movement and Large Farmers" Organization." in Carl C. Taylor, Douglas Ensminger, T. Wilson Longmore, Louis J. Ducoff, Arthur F. Raper, Margaret J. Hagood, Walter C. McKain, Jr., and Edgar A. Schuler, Rural Life in the United States, New York: Alfred A. Knopf.

1949 "Significant Trends and Direction of Change." in Carl C. Taylor, Douglas Ensminger, T. Wilson Longmore, Louis J. Ducoff, Arthur E. Raper, Margaret J. Hagood, Walter C. McKain, Jr., and Edgar A. Schuler, Rural Life in the United States. New York: Alfred A. Knopf.

1953 The Farmers' Movement, 1620-1920. New York: American Book Company.

Toch, Hans

1965 The Social Psychology of Social Movements. Indianapolis: Bobbs-Merrill Company.

Turner, Ralph $\mathrm{H}$, and Lewis M. Killian

1957 Collective Behavior, Englewood Cliffs, N.J.: Prentice-Hall.

Vankirk, Jay R.

1978 "Will the 'Strike' Strike Out?" Kansas Farmer (January 7):18, $22 a$. 
Wilkening, Gene

1978 "Wisconsin Farmer Survey." Madison: Department of Ruteal Sociology, University of Wisconsin.

Zald, Mayer N. and Roberta Ash

1966 "Social Movement Organizations: Growth, Decay, and Change". Social Forces Vol 44, No. 3 (March):327-41

Zald, Mayer N. and John D. McCarthy

1972 "America and the Rise of Social Movements." New Society Vol. 20, No. 509 (June):670-2.

\section{HEALTH SELF-REPORT CORRELATES AMONG OLDER PEOPLE IN NATIONAL RANDOM SAMPLE DATA}

Marshall J. Graney

Wayne State University

\section{Renee M. Zimmerman}

University of Kansas

Mid-American Review of Sociology, 1980, Vol. V, No, 2:47-59

Older people's health self-reports (HSRs) are frequently cited in explanations for changes in social status (e.g., retirement), social participation-activity (e.g., disengagement), and personal attitudes (e.g., life satisfaction). The purpose of research reported here was to establish correlates of HSRs in U.S. national random sample data. The parametric analysis strategy was applied to data on all persons aged $65+$ interviewed for the Harris-NCOA survey $(N=$ 2797), with results as follows: social status (2 variables, largest $\left.r^{2}<0.15\right)$, social participation-activity $(5$ variables, largest $\left.r^{2}<0.25\right)$, and personal attitudes $\left(10\right.$ variables, largest $r^{2}<$ $0.15)$. Ail variables analyzed were correlated to HSR at the 0.001 level or beyond. These results confirm findings from studies using smaller or specialized samples, and they present new evidence of the importance of social participation-activity to the HSRs of older people.

\section{INTRODUCTION}

Purpose and Scope

The importance of health in the lives of older people is shown by the fact that personal health is one of the most frequent explanations they offer for changes in social status (e.g., retirement), social participation-activity (e.g., disengagement), and personal attitudes (e.g., life satisfaction). Research has shown that the attitudes and behaviors of older people are more closely related to their health self-reports (HSRs) than to physiologicalmedical evaluations of health by others (Friedsam and Martin, 1963; Maddox and Douglass, 1973), which demonstrates the importance in HSRs. 